\title{
Quantum Physics and Mathematical Aided Proof of Theory 1 of Boy'o Universal Theory of Therapy (BUTT)
}

Manly Sani*

Department of Human Physiology, Faculty of Medicine, Ahmadu Bello University, Nigeria

\begin{abstract}
The finding determines the dependence of body processes on STP and MCT, six processes which occur in the isolated rabbit ileum were used to prove the statement of the theory 1 of BUTT, mainly effects of extract and Autonomic drugs on isolated rabbit ileum together with novel mathematical principles were used to show that seven normal processes (motility, secretion, metabolism, circulation, immunoreactivity, absorption, digestion) of the isolated rabbit ileum are directly proportional to activated STP and MCT and inversely proportional to inactivated STP and MCT given as, $\boldsymbol{R}_{s} \propto \frac{N_{i}}{N}$ and thus $\boldsymbol{R}_{s}=K \frac{N_{i}}{N_{i}}$

Acknowledge that from the above relation, STP responses $R_{s}$ was used base on the assumption that all body processes are responses of STP and MCT, in other words, body processes are manifestation of STP response, thus First and foremost, I posit that any number of response $\left(R_{s n}\right)$ or magnitude of response $\left(R_{s m}\right)$ is a function of or proportional to activated STP backbones $\left(N_{i}\right)$ and inversely proportional to inactivated STP backbone $\left(N_{y}\right)$.

i.e. $R_{s} \propto \frac{N_{i}}{N_{y}}$ and thus $R_{s}=K \frac{N_{i}}{N_{y}}$

$\mathrm{K}$ is a universal constant proportionality of therapy.

To estimate $N_{i}$ for each receptor in the isolated rabbit ileum, I determined number of molecules $(N)$ for each drug and extract and number of molecules $\left(N_{x}\right)$ towards the receptor direction, also using a biomarker (isolated rabbit ileum) the magnitude of effect (contraction and relaxation) of extract/drugs on the ileum was determined by combination interactions, novel mathematical equations and quantum physics, which gave me insight about the autonomic nature of the extract. Again from the combination interaction of antagonists and agonists with the extract as well as novel mathematical equation and calculation, I deduced the receptor types which combined with the extract, the couple receptor types, and the linked cascades in un limited sense of their complexity, in spite that past finding have unraveled various receptor types, limitations of characterization and crystallography abounds and so warrant use of mathematic to gain useful insight, interestingly, observed height, STP components' flux time and mathematically determined magnitude of response $\left(R_{\mathrm{sm}}\right)$, shows strong correlation, of course as found in other findings, we assumed that alternating responses seen was due to bimodal on or off switches peculiar to STPs and MCT, these act in turn to activate many targets and therefore more than two responses might have occurred as predicted from various novel equation and calculation. The seven processes investigated are; directly; motility, indirectly; secretion, epithelial protein synthesis and transluminal absorption, digestion, circulation, and immunoreactive processes respectively, as a matter of veracity, it important to state that only the result of isolated rabbit ileum motility was obtained from which other processes were inferred from perspective of STP and MCT vital cascade components using platform of mathematics, in so far as this remain the case, the principle of hypothesis was investigated and lead to the emergence of Boy'o Universal Theory of Therapy (BUTT) 1,
\end{abstract}

Theory 1 of BUTT called dependence theory states that any process; pathologic, physiologic, biochemical, genetic, metabolic and congenital occurring in the body, including drug efficacy and drawback, is directly proportional to activated signal transduction pathways (STPS) and inversely proportional to inactivated ones provided that MCT remains constant.

The result was subject to both statistical analysis and mathematical calculation, for the statistical result standard deviation was 1.05 and magnitude of response $\left(R_{\text {sm }}\right)$ was 27.996 at number of active components (Nc1) of 0.7 to indicate inactivation of STPs, other values show activation, a fact that is of clinical, pharmacological, and biomedical importance.

Keywords: Quantum physics; Molecular cross talk; Signal transduction pathways

\section{Introduction}

The finding test the hypothetical statement of theory 1 of Boy'o universal theory of therapy (BUTT 1), it maintained that any process in body depends on STP and MCT interaction, signaling medium enumerated in most literature shed light on genesis of various processes in the body [1], be they binding or non binding actions, STP encompass complex interrelated series of communicating cascades of proteins and enzymes, each cascade have particular attributes which they utilized in processes of transduction, they transmit signals by assigning roles to each cascade components and in this regard, adapter, recruiter,
*Corresponding author: Manly Sani, Department of Human Physiology, Faculty of Medicine, Ahmadu Beloo University Zaria, Abuja, Nigeria, Tel: 2347067151787; E-mail: sanitime2014@gmail.com

Received May 08, 2015; Accepted August 10, 2015; Published August 17, 2015

Citation: Sani M (2015) Quantum Physics and Mathematical Aided Proof of Theory 1 of Boy'o Universal Theory of Therapy (BUTT) . J Med Diagn Meth S1: 005. doi: 10.4172/2168-9784.S1-005

Copyright: (C) 2015 Sani M. This is an open-access article distributed under the terms of the Creative Commons Attribution License, which permits unrestricted use, distribution, and reproduction in any medium, provided the original author and source are credited. 
amplifier, deactivators and other forms exist, so that by 'on' and 'off' mode, signal is amplify down the cascade stream, how these event are mediated by many interconnected pathway backbone is remains to be demystified completely, which is why I incorporated mathematical equations and calculation in this study, importantly, the calculation and novel equation serve effective tool which handles the complexity of STP and MCT, the organ bath/drug bioassay essentially ensured determination of the autonomic nature of the extract from contraction and relaxation response observed when extract and drugs interact with the receptors on the isolated rabbit ileum in organ bath, the autonomic nature of extract so determined furnished the result from which the mechanism of action of extract as it relate to signal transduction pathways $\{$ STPs $\}$ of seven of the isolated rabbit ileum were inferred in accordance to stipulation of previous literatures, for instance Ganong [2] show that certain autonomic action are mediated via muscarinic and adrenergic receptors as well as their respective STPs such as cAMIP3-PKA pathways. Qingzhen et al. [3] showed that ras/raf/MEK/ERK signal transduction cascade is at the heart of signaling network that governs proliferation, differentiation and cell survival (Table 1).

Additionally the signal transduction of most receptors types and subtypes activated in seven GIT processes (Motility, secretion, metabolism, absorption, immunoreactivity, circulation and digestion) of the isolated rabbit ileum which have bearing to the bioassay had been described by past findings, therefore it was possible to asses STP cascade involves in the seven processes with aid of quantum physics and mathematics principles and then go ahead to prove that their occurrence would not have been without the presence of STPs, actual experiment use motility processes, from which together with mathematical principles other STPs mediated processes were determined, Morrison and Davis, [4] shows that MPKs pathways are positively regulated by several mechanisms which include scaffold proteins. The layout of this finding can be extrapolated to ones involving body abnormality and drug toxicity, given that STPs determine all processes of the body, body processes are manifestation of STP responses, instance gene transcription, contraction of heart muscle, cellular uptake of glucose etc. are STP responses in physiologic manifestation. The benefits of application of the theory as detail in subsequent sections of this finding are priceless. Imagine a world free of body abnormality, drug adverse effects (side effect, toxicity etc.), effective determination of Rsm values will form linked between used and gauging of STPs activities in biomedical research, drug development, drug safety profiles determination, and use of target hit in relation to treatment.

\section{Incidence}

The incidence of body abnormalities and drug toxicity as they relate to STP and MCT certainly could be said to have assumed a universal status, in that STP and MCT are cosmopolitan in the body, again all diseases, abnormalities, normal processes and drug uses in the world have STPs factors [5].

\section{Statement of the problem}

The proposed concept that all processes occurring in the body depends on STP and MCT remains to be proved, again the fact that all body processes are manifestation of STP and MCT responses remains to be validated, especially looking at it far reaching implication on theory 2 and 3 of BUTT which aim to control and regulate STP and MCT globally, treat abnormalities and eliminate drug adverse effects, for in spite that these incapacitating abnormalities affect everyone in all the nook and cranny of the universe irrespective of the geographical nature of the place across the globe, there is limitedness in application, owing to the inability of research to unravel limitless realistic benefits of STP as sort by these findings, investigators lacking in STP assessment equipment abound, they can use BUTT1 principles.

\section{Aims and Objective}

To know the sympathetic and parasympathetic nature of the extract om drug action on smooth muscles of the rabbit ileum.

To determine from the result of combination interactions; quantum physics, chemistry principles and new mathematical equations, the types and subtypes of receptors, mechanism of action, receptor selectivity of extract and drug, from perspective of synergism, antagonism interactions, so as to get insight about dependence of seven processes of isolated rabbit ileum on STP and MCT.

To validate the propounded BUTT1 with aid of the statement of the hypothesis, mathematical and experimental results.

To experimentally (biomarker bioassay) and empirically, using mathematical equation and STP diagrams, show how the experimental result confirms the hypothetical statement as well as the propounded theory.

\section{Scope and Limitation}

\section{Scope}

The scope of this finding encompass the fields of human physiology, clinical pharmacology, gastroenterology, neurology, proteomic, transcriptomic and genetic (genomics) and molecular biology, human anatomy and mathematics all of which are related fields of biomedical sciences, the array and the expanse of the scope becomes inevitable due to complex nature of STP in GIT motility and other processes.

\section{Limitations}

The limitations lies in the fact that animal GIT and not human GIT was used in the bioassay which is also an in vitro exercise. Again lack of logistics was a major experimental constrained in that STP in pragmatic aspect use bioassay of extract and notwithstanding the validity of experimental exercise, advance approach with sophisticated equipment would have been preferred.

Another notable limitation is accurate protein characterization and data analysis in field of proteomics which need novel methods of investigation occasioned by complex nature of novel biomedical ideas like this one, requiring proteomics instrumental arsenal, Again, high avalanche of data output needs new mathematical and computation models (Boy'o) [6].

\section{Justification of the study}

It will lay foundation work for validation of theory 2 and 3, again these theories aim to treat completely and successfully various abnormalities, eliminate drug toxicity, and open diverse opportunity in biomedical research, especially use of STP and MCT in treatment and drug formulation.

More so, Recent and past findings indicated that small sample size, limited data, techniques and result of most studies makes proteomics and relevant findings underpowered to detect small to moderate differences, which necessitate the novel mathematically formula and use of some concepts of quantum physics, the equations I derived and how it in vivo application, probe concentration and number of molecule can be related to STP for vital deductions so that individual view of cascades and cascade components can be linked together for 


\begin{tabular}{|c|c|c|}
\hline Group A single interaction & Height (cm) & Standard deviation \\
\hline Ach $2 \mathrm{ug} / \mathrm{ml}$ of $0.1 \mathrm{ml}$ & 3.5 & 0.42 \\
\hline Ach $2 \mathrm{ug} / \mathrm{ml}$ of $0.2 \mathrm{ml}$ & 4.1 & 1.33 \\
\hline ADR $10 \mathrm{ug} / \mathrm{ml}$ of $0.2 \mathrm{ml}$ & 2 & 0.12 \\
\hline ADR $10 \mathrm{ug} / \mathrm{ml}$ of $0.4 \mathrm{ml}$ & 1 & 0.4 \\
\hline $\mathrm{DR} 1 \mathrm{mg} / \mathrm{ml}$ of $0.8 \mathrm{ml}$ & 1.5 & 0.08 \\
\hline $\mathrm{DR} 10 \mathrm{mg} / \mathrm{ml}$ of $0.2 \mathrm{ml}$ & 0.9 & 0.52 \\
\hline $\mathrm{DR} 10 \mathrm{mg} / \mathrm{ml}$ of $0.4 \mathrm{ml}$ & 1 & 0.4 \\
\hline $\mathrm{DR} 10 \mathrm{mg} / \mathrm{ml}$ of $0.8 \mathrm{ml}$ & 0.5 & 1.27 \\
\hline DR $100 \mathrm{mg} / \mathrm{ml}$ of $0.2 \mathrm{ml}$ & 0.2 & 2.68 \\
\hline $\mathrm{DR} 100 \mathrm{mg} / \mathrm{ml}$ of $0.4 \mathrm{ml}$ & 0.1 & 4.11 \\
\hline $\mathrm{DR} 100 \mathrm{mg} / \mathrm{ml}$ of $0.8 \mathrm{ml}$ & 0.4 & 1.58 \\
\hline $\mathrm{SO} 1 \mathrm{mg} / \mathrm{ml}$ of $0.8 \mathrm{ml}$ & 2.5 & 0.69 \\
\hline SO $10 \mathrm{mg} / \mathrm{ml}$ of $0.2 \mathrm{ml}$ & 3 & 0.92 \\
\hline SO $10 \mathrm{mg} / \mathrm{ml}$ of $0.4 \mathrm{ml}$ & 2.8 & 0.83 \\
\hline SO $10 \mathrm{mg} / \mathrm{ml}$ of $0.8 \mathrm{ml}$ & 1 & 0.4 \\
\hline SO $100 \mathrm{mg} / \mathrm{ml}$ of $0.2 \mathrm{ml}$ & 0.5 & 1.27 \\
\hline SO $100 \mathrm{mg} / \mathrm{ml}$ of $0.4 \mathrm{ml}$ & 0.3 & 2 \\
\hline SO $100 \mathrm{mg} / \mathrm{ml}$ of $0.8 \mathrm{ml}$ & 0.1 & 4.11 \\
\hline DR $100 \mathrm{mg} / \mathrm{ml}$ of $0.4 \mathrm{ml}$ & 0.7 & 0.83 \\
\hline DR $100 \mathrm{mg} / \mathrm{ml}$ of $0.8 \mathrm{ml}$ & 0.1 & 4.11 \\
\hline SO $0.1 \mathrm{mg} / \mathrm{ml}$ of $0.8 \mathrm{ml}$ & 3.3 & 1.04 \\
\hline $\mathrm{SO} 0.1 \mathrm{mg} / \mathrm{ml}$ of $0.4 \mathrm{ml}$ & 2 & 0.12 \\
\hline SO $10 \mathrm{mg} / \mathrm{ml}$ of $0.2 \mathrm{ml}$ & 2.3 & 0.59 \\
\hline
\end{tabular}

Table 1: Shows result of single interaction of drug and extract. Note SO: Senna obtusifolia, DR: Duranta repenes, Ach: acetylcholine, ADR: adrenaline.

accurate global view. All of these problems and solution proffered justify the laudable effort of these findings. The finding once again will be of important benefits to future research, the hallmark of STPs findings will be ability to combine probe + medcament+labbeled isotope at concentration or number of molecules deem save in addition to on screen in vivo real time visualization of their actions (Boy'o) [7], also mathematical insight will aid target hit in research and clinical setting.

\section{Statement of Hypothesis}

(1) States that any processes in the body is directly proportional to activated signal transduction pathways (STP) and inversely proportional to inactivated ones if MCT is constant.

(2). Body processes are manifestation of STP and MCT responses in order words body processes are STP and MCT responses.

\section{Literature Review}

Current and recent research work had exploited the benefit of signalling medium especially with global increase in therapeutic drawbacks such as body accommodation to therapy, drug resistances by pathogens, incurable disease such as cancer, also complex nature of STPs limit their application in most biomedical research, it was due to complex nature of STP that made researchers resort to use of wave concept in STPs investigation, example kolodenko (2006) shows that use of physical principles may cement our understanding of mechanism of Signaling medium, additionally most research work attribute causal effect of biological and physiologic processes to STPs, again countless finding have attributed countless STPs to mediums which initiate and direct various cellular processes, again the link between most characterize receptors and their STPs have not been established completely, for instance known few are $G$ protein couple receptors which act through cAMP, PLC and PKA or calcium channels, WNT act through the GSK/3B/APC/ cascades, $\mathrm{E}$ cadrin act via $\mathrm{B}$ catenin, and growth factors TGFa act through RTK/SOS/Ras/ cascades, in addition survival factors (TGF1) act via the following cascade [8] RTK/P13K/AKT and of course cytokine mediate their STP response via JAk/STAT pathways, of these pathways $G$ protein can't be studied in crystallized form a lacuna in investigational front [9].

STP mechanism in other organisms, in mechanism of action of cholinomimetics at cytoplasm domain, the co-transporter such as $\mathrm{Na} / \mathrm{K} / \mathrm{Cl}$ act on kinase to initiate up stream or downstream cascade activation, facts implicated in pathogenic life cycles. According to recent investigation there are no known processes in which occur without the fundamental input of the STP and MCT, physiologically, cardiovascular system is regulated by STP and MCT acting on the vascular endothelium to cause vasoconstriction of arterioles, the arterioles actually determine the blood pressure against which the heart contract to pump blood, in heart failure, cardiomyocetes hypertrophy and occluding angiogenic plaques were implicated and they never occur without STPs input. Findings show the roles of TNF alpha signaling pathways is suspected to mediate the apoptosis, it employ AKT, JUN kinase pathways however Gainluigi et al. [10] shows that many of the pathways are unknown another lacuna which warrant use mathematical manipulation to gain insight about them, during development in $\mathrm{C}$ elegans and presumably humans, $\mathrm{RAC} /$ CDC-42- independent GIT PIX/Pak were involve in cell migration (Mark et al.) [11]. Cell migration is vital for development and maintenance of tissues in the body, research shows that most of the embryological processes are control by STP and MCT, Reichrath and Reichrath [12] shows that notch signaling in embryology have provided more knowledge about possible use of prophylaxis and treatment patterns in cancer, it has enable researchers make ground breaking discovery in cellular and molecular pathology. Other findings have also recognize the vital roles of signaling medium in embryology for instance in cardiac development, Gaudix et al. [13] reported that epicardial derived signal are key regulator of cardiac development in embryo, in the study retonic acid (RA) receptor dependent mechanism was adduced as the main controller of the heart development, given that RA is synthesize by raldh enzymes, in spite it role in morphogenesis of the heart, the basic mechanism of it transcription is largely unknown (another lacuna), Gaudix went further to discover that Wt 1 null cells portray a trend where decrease in RA synthesis was noted and that RA related receptors (PDGFR $\alpha, \beta$ and $\mathrm{RXR} \alpha$ ) undergo down regulation when Wt 1 is absent., this signaling medium and significant others direct cell movement and migration in development of organs found in various systems in the body, example Human notch 1 is involve in initiating juxtacrine signal between apposed cells, also notch promote proliferative signaling during neurogenesis, it actions are antogonised by numb to allow for the process of neural differentiation, Brou et al. [14] show that notch signaling are involve in proteolytic cleavage.

Finding demonstrated that signaling medium maintain normal concentration of glucose during biochemical processes, glucose 
synthesis in the muscles, hepatic uptake in the liver as directed by presence or absence of insulin requires STP and MCT, again it is not during normal processes that STP and MCT play indispensible roles in biochemical processes, in defective metabolism of type II diabetes for instance, there is impairment in stimulation glycogen synthesis in skeletal muscle by insulin, the activation of signaling cascade in which GS kinase at site 3 is phosphorylated and thus called (GSK)-3, Reza et al. [15] show that dephosphorylation is mediated by glycogen bound form of protein phosphotase (PP)1 , again he posit that there evidence pointing at the fact that insulin activate GS by inhibiting GSK-3 to mediate the biochemical processes of glucose synthesis or uptake as the case may warrant.

Signaling medium have been implicated in many genetic processes of proteins synthesis such transcription, translation and post translational modification, and in nucleic acid degraded metabolism. Again the finding reported that in many form of genetic disease or abnormalities, numerous cascades of signaling medium are involved, for instance in polycystic kidney disease (PKD), STP component was use as targets, although not as individual bloc but network of communication due to the following characteristic; inactive state, reciprocal reinforcement, feedback loops, one of the reason behind the use of STP target was for the following reasons, up-regulations of B-Raf/Mek/ERK/, P13/AKT and Wnt/B-catening pathways, MYC and HIF transcription factors, down regulation of the LKB1/AMPK/TSC pathway. GSK3 and P53 promoted glycolysis and progression of cell cycle Peter and Vicente [16]. In another type of genetic disease investigation Pohler et al. [17] shows that integrin $3 a$ is a transmembrane integrin receptor, it basic roles encompass control and regulation of signaling between cells and their micro environment, absence of integrin $3 a$ was associated with following abnormalities; fragile skin, Lung organogenesis, and abnormal kidney (Table 2).

In pathology which concerns mitochondria disease, research shows that defect in mitochondria calcium accumulation have been shown to correlate with a defect in ATP production, also mitochondria $\mathrm{C} 2+$ signaling was implicated in the group of disease emanating from mitochondria defects Brimi [18], in other types of pathologies; viral, bacterial, parasitic etc., the signaling medium were portrays as primary medium of control and regulatory processes leading to pathogenesis, for instance in SOCS3 signaling medium in hepatitis, SOCS negatively inactivate TNFa signaling medium in viral mediated hepatitis, again in microbial disease, toll like receptor (TLR) and myloid differentiation factor 88 (MyD88) are key factor which activate innate immune defense when there is microbial infestation in the body, using S. pneumoniae in mice, Barbara et al. [19] demonstrated that activation of MyD88 STP was very important for initiating host defense response against the bacterial attack, the preceding paragraph are far less continuum of examples of involvement of STP and MCT in various findings, in fact nowadays, hardly would a researcher conduct study without dipping into the role of STP and MCT in the processes of research interest, studies on most pathways is currently at various stage, intricate nature of some pathways are completely unknown which is why mathematical model is necessary for global view of STPs also included in this regard is clinical treatment, drug formulation, indeed impact of STP and MCT in the body systems is all encompassing and universally true.

It is not contestable that single event like immunologic processes could activate several pathways, Chen et al. [20] that activation of Toll pathway, IMD pathway and JAK/STAT pathway and so on happens during antigenic attack.

\section{Receptors, Signal Transduction Pathway and Molecular Cross Talking}

\section{Receptors roles in STP}

They are binding moiety found on cell membrane extracellular or intracellular or ECM, the have important binding region which makes binding between ligand and receptor specific, latter depends on shape, size, and charge distribution of the ligand, note that some reaction do not activate STP directly, neutralisation reaction for instance don't activate STP since binding is not involve but assuredly, as would be anticipated, the product of the reaction ultimately requires binding and STP activation, STP cascade component are complex, in one instance several protein components may be formed, in order to up regulate or down regulate a given streams of cascade, Additionally, Takashi et al. [21] showed that delineation of pathway is consistent with the formation of functional unit by M2-Go protein and M3 PLC system.

\section{Signal Transduction Pathway (STP)}

The basic aim of STP and MCT is to transducer signal in line with physiological or biological response in sight, it is crucial to note that constituent of STP are many and diverse, they use various ways to assemble cascade component most of which are localized in surrounding where they occur, I called the latter component 'peripheral factors' (PF).

Research show that mobility of a cascade components may affect it roles, Once activated, the last protein kinase in the cascade translocates to the nucleus where it phosphorylates and activate specific transcription factors such as EIK-1 or rectify KAT1 channels (Berkowitz) [22] research shows that amplification pathways could be base on and off switches, example according to Morrison and Davis [4], scaffold protein regulate positively and negatively MPAKS pathway.

\section{Materials and Methodology}

\section{Materials}

Animal : Rabbit, Organ bath apparatus, Tyrode solution, Petri dish, Scissors, Needle, syringe Thread, Oxygen source, Microdynamometer, Beaker, timer, kymograph, Dissecting kit, Transducers Thermometer, Conical flask, Weighing scale, Dissecting table, Distilled water, plants used for crude extraction of active ingredient are Senna Obtusifolia and Duranta repens.

\section{Addition of Drug and Extract Assay}

\section{Plant collection and identification}

The two plants used were obtained from Samaru in Zaria Kaduna state northern Nigeria, West Africa, Senna obtusifolia (V/No 1370) and

\begin{tabular}{|c|c|c|}
\hline Group B double interaction & $\begin{array}{l}\text { Height } \\
\text { (cm) }\end{array}$ & Standard deviation \\
\hline SO $10 \mathrm{mg} / \mathrm{ml}$ of $0.8 \mathrm{ml}$ and $0.5 \mathrm{ug}$ of $0.1 \mathrm{ml} \mathrm{ca}$ & 6.5 & 1.05 \\
\hline SO $10 \mathrm{mg} / \mathrm{ml}$ of $0.8 \mathrm{ml}$ and $2 \mathrm{ug}$ of $0.1 \mathrm{ml}$ ach & 6.5 & 1.05 \\
\hline $\begin{array}{c}\mathrm{DR} 10 \mathrm{mg} / \mathrm{ml} 0.8 \mathrm{ml} \text { and ADR } 10 \mathrm{ug} / \mathrm{ml} \text { of } \\
0.8 \mathrm{ml}\end{array}$ & 1 & 2.5 \\
\hline $\mathrm{SO} 10 \mathrm{mg} / \mathrm{ml} 0.2 \mathrm{ml}$ and ADR $10 \mathrm{ug} / \mathrm{ml} 0.2 \mathrm{ml}$ & 1.1 & 2.28 \\
\hline
\end{tabular}

Table 2: Shows result of double interaction between drugs and extract $\mathrm{Ca}$ cabachol. 
Durante repens respectively belong to Leguminosae and Verbenacea family, they were identify by department of biological science herbarium faculty of science Ahmadu Bello University Zaria.

\section{Plant sample preparation and phytochemical screening}

Plant extract preparation: The leaves of the two plants obtained from their natural habitat were tried for two weeks at room temperature, subsequently, each of the tried leaves was macerated manually, then in the lab, the weight of the crushed extract was determined using electrical weighing apparatus, the determined weight of Durante repens and Senna obtusifolia are $132.09 \mathrm{~g}$ and $100.84 \mathrm{~g}$ respectively, after maceration of each of the plant leaves, the grit obtained was soaked in $900 \mathrm{ml}$ (Duranta repens) and $600 \mathrm{ml}$ (Senna Obtusifolia) of 700 $\mathrm{ml}$ methanol which was diluted with $300 \mathrm{ml}$ of water and allowed to stand for 3 days, filtration was carried out with the aid of sieve covered with funnel in which liquid extract was separated from the Mac, the liquid extract was poured gently into the evaporating dish, set at $40 \mathrm{C}$ to facilitate evaporation and solidification of extract isolated from the dried leaves of $D$. repens were exhaustively extracted with $85 \%$ methanol. NB in most methanolic extract Anthraquinone is absent and anticipated few number of contraction response as seen in the result of bioassay.

\section{Experimental Animal}

The experimental animals used were matured New Zealand rabbits.

\section{Methodology}

\section{Animal preparation}

The rabbits were housed in animal house for 3 days to acclimatize, they were given clean water and animal feed, also the animals were treated base on best international practice, eventually, they were fasted for 24 hours in order to allow for clearance of ileal luminal contents, each rabbits was then sacrificed humanly, and many pieces of the Ileum of about $3 \mathrm{~cm}$ were dissected out and carefully placed into Petri dish containing tyrod solution, after aeration with oxygen, a thread was tied through one of the lower wall of the $3 \mathrm{~cm}$ piece of the ileum, another thread was sewed in the upper part of the dissected $3 \mathrm{~cm}$ ileum which was attach to the organ bath, then speed and sensitivity of microdynamometer was adjusted and set at $24 \mathrm{~mm} / \mathrm{min}$ and $2 \mathrm{mv}$ respectively.

\section{Addition/interaction of drug and extract}

In the Bioassay therefore, the following interaction was done; 0.1 $\mathrm{ml}, 0.2 \mathrm{ml}, 0.3 \mathrm{ml}, 0.4 \mathrm{ml}, 0.8 \mathrm{ml}$ volumes respectively for each of $1 \mathrm{mg} /$ $\mathrm{ml}, 10 \mathrm{mg} / \mathrm{ml}, 100 \mathrm{mg} / \mathrm{ml}$ doses of extracts alone or in combination with drugs, for drugs interactions doses and drugs used are ach $2 \mathrm{ug} /$ $\mathrm{ml}$, carbachol $0.5 \mathrm{ug} / \mathrm{ml}$, physostigmine $80 \mathrm{ug} / \mathrm{ml}$, adrenaline $10 \mathrm{ug} /$ $\mathrm{ml}$, atropine $10 \mathrm{ug} / \mathrm{ml}$, nicotine $10 \mathrm{ug} / \mathrm{ml}$, The drugs and was added in three mode, firstly in single form, secondly in double form and thirdly in triple form, similarly the extract in combination with the drug was added and their individual effect on the GIT was noted from reading on physiograph, also binding time between the drug or extract molecules and the various receptors on the GIT was noted, again we determined the terminal velocity, number of molecules from drug and extract concentration in order to know the number of cascade activated or inhibited and the time it was activated, other parameter are cascade flux velocity, response time of each cascade.

\section{Measurement and calculations}

Stock preparation of extract: $1 \mathrm{mg} / \mathrm{ml}, 10 \mathrm{mg} / \mathrm{ml}$ and $100 \mathrm{mg} / \mathrm{ml}$ of each of the extract was used in the combination interaction

Step (1) $1 \mathrm{gm}$ of extract each was weighed and dissolved in $10 \mathrm{ml}$ of water i.e. $1 / 10=0.1 \mathrm{~g} / \mathrm{ml}$ and $0.1 \mathrm{~g} / \mathrm{ml} \times 1000=100 \mathrm{mg} / \mathrm{ml}$. Step (2) $1 \mathrm{ml}$ of $100 \mathrm{mg} / \mathrm{ml}$ was taken from above to make up to $10 \mathrm{ml}$ of the solution meaning that $100 \mathrm{mg} / \mathrm{ml}$ is contained in $10 \mathrm{~m}, \mathrm{X} \mathrm{mg} / \mathrm{ml}$ is contained $1 \mathrm{ml}$ And thus $100 \times 1 / 10=10 \mathrm{mg} / \mathrm{m}$. Step (3) $0.1 \mathrm{ml}$ of 10 $\mathrm{mg} / \mathrm{ml}$ was taken from above to make up to $1 \mathrm{ml}$ of the solution thus 10 $\mathrm{mg}$ contains in $1 \mathrm{ml}, \mathrm{X} \mathrm{mg}$ contain in $0.1 \mathrm{ml}$ and $10 \times 0.1 / 1=1 \mathrm{mg} / \mathrm{ml}$, Therefore stock of extracts each are $1 \mathrm{mg} / \mathrm{ml}, 10 \mathrm{mg} / \mathrm{ml}$ and $100 \mathrm{mg} /$ $\mathrm{ml}$, Dose preparation of extract are $10 \mathrm{mg} / \mathrm{ml}$ is the stock concentration of the extract Thus $10 \mathrm{mg}$ is contain in $1 \mathrm{ml}, \mathrm{Xmg}$ is contain in $0.1 \mathrm{ml}$, Therefore $\mathrm{X} \mathrm{mg}=0.1 \times 10 / 1=1 \mathrm{mg}$, Meaning that, $1 \mathrm{mg}$ is contain in $1.038 \mathrm{~kg}$ (weight of rabbit), But X mg contain in $1 \mathrm{~kg}$ And thus $1 \times$ $1 / 0.911=1.097 \mathrm{mg} / \mathrm{kg}$, Therefore the dose of extract is $1.097 \mathrm{mg} / \mathrm{kg}$.

Volume used: Volume $=$ dose $\times$ weight of rabbit/stock, thus $1.097 \times$ $0.911 / 10=0.1 \mathrm{ml}$ Therefore $0.1 \mathrm{ml}$, then $0.2 \mathrm{ml}, 0.4 \mathrm{ml}$ and $0.8 \mathrm{ml}$ were used Concentration of extract in organ bath also for Duranta repens

Stock concentration extract $(\mathrm{C} 1)=10 \mathrm{mg} / \mathrm{ml}$, Volume of extract added $(\mathrm{V} 1)=0.2$, Organ bath volume $(\mathrm{V} 2)=10 \mathrm{ml}$, Organ bath concentration $(\mathrm{C} 2)=$ ?, $\mathrm{C} 1 \mathrm{~V} 1=\mathrm{C} 2 \mathrm{~V} 2$ and thus $\mathrm{C} 2=\mathrm{C} 1 \mathrm{~V} 1 / \mathrm{V} 2,=10 \times$ $0.2 / 10,=0.2 \mathrm{mg} / \mathrm{ml}$, Thus, conc. of each extract in organ bath is $0.2 \mathrm{mg}$ for $10 \mathrm{mg} / \mathrm{ml}$ (stock), $2 \mathrm{mg} / \mathrm{ml}$ for $100 \mathrm{mg} / \mathrm{ml}$, (stock), $0.02 \mathrm{mg} / \mathrm{ml}$ for 1 $\mathrm{mg} / \mathrm{ml}$ (stock), using above formula C2 at other volume $(0.1,0.2,0.3,0.4$, 0.8 ) was be determined, it is crucial to note that in proving the BUTT we simply test hypothetical assumption using mass formulas, but putative probe could replace either drug or the extract since all are essentially molecules. Organ bath concentration for drugs include Ach $\mathrm{C} 1=2 \mathrm{u}$, $\mathrm{V} 1=0.2, \mathrm{C} 2=$ ?, $\mathrm{V} 2=10 \mathrm{ml}$, but $\mathrm{C} 2=\mathrm{C} 1 \mathrm{~V} 1 / \mathrm{V} 2$ and $2 \times 0.2 / 10=0.04 \mathrm{ug} / \mathrm{m}$ i.e. for Ach for others drugs the organ bath concentration (C2) are 0.04 $\mathrm{ug} / \mathrm{ml}$ ach at $2 \mathrm{ug} / \mathrm{ml}$ (dose), $0.01 \mathrm{ug} / \mathrm{ml}$ carbachol at $0.5 \mathrm{ug} / \mathrm{ml}$ (dose), $2.4 \mathrm{ug} / \mathrm{ml}$ physostigmine at $80 \mathrm{ug} / \mathrm{ml}$ (dose), $0.4 \mathrm{ug} / \mathrm{ml}$ adrenaline at $10 \mathrm{ug} / \mathrm{ml}$ (dose), $0.2 \mathrm{ug} / \mathrm{ml}$ atropine at $10 \mathrm{ug} / \mathrm{ml}$ (dose) and $0.6 \mathrm{ug} / \mathrm{ml}$ nicotine at $500 \mathrm{ug} / \mathrm{ml}$ (normal dose) NB volumes used are $0.1,0.2,0.3$, $0.4,0.8$ for each of above drug, extract.

\section{Result and Discussion}

\section{Result}

Selected result from many combination interactions.

\section{Discussion}

Theory one was proved from two perspectives

(1) Experimental proof; which include: (a) Bioassay of biomarker (rabbit ileum) and (2) Mathematical proof; which include (a) algebraic equations and (b) calculus derivative arrived at from experimental deductions.

\section{Proof of Theory 1 of Butt}

Experimental proof: as shown in the result obtained above, I used combination interactions (synergism, potentiation and inhibition) of antagonist and agonist drugs with extract to deduce the following: (1) The autonomic nature of the extract and hence the receptor types which combined with the extract deduced from drug action of Table 1 ( $2 \mathrm{ug} /$ $\mathrm{ml}$ of acetylcholine and $10 \mathrm{ug} / \mathrm{ml}$ of adrenaline height recorded are 4.1 $\mathrm{cm}$ and $1 \mathrm{~cm}$, standard deviation are 1.33 and 0.40 respectively), Senna obtusifolia and Duranta repens maximum height was $3.3 \mathrm{~cm}$ and 1.5 respectively at 1.40 and 0.08 standard deviation, which validate their autonomic nature, meaning that the extracts acted via $G$ protein and 
possibly via other receptors as the atypical nature of contractions show, but recall that we in interested in proven that the seven processes which occur in the isolated rabbit ileum were dependent on STPs, firstly we show that as far as autonomic action of the drugs are concern, they must have acted through adrenergic or muscarinic receptors, we suspected other dose dependent non autonomic actions of extract via other receptors which may or may not be G protein coupled, these receptors includes but not limited to dopamine, 5HT, adenosine, NK, VGF, EGF, NK1, NK2, T1R, T2R, and transducin in addition to their subtypes which are GPCRs, RTKs, integrin etc., Senna obtusifolia generally, at low dose caused contraction (Tables 1 and 2) $(1 \mathrm{mg} / \mathrm{ml}$ of $0.8 \mathrm{ml}$ height was 2.5 , however at $10 \mathrm{mg} / \mathrm{ml}$ of 0.8 relaxation was seen, standard deviation was 0.69 and 0.40 respectively), the mode of action of drug and extract shows that many STPs and MCT were activated, as shown in mathematical proof, for instance as far as the seven processes are concern, Binding between drug or extract molecules activated ECM receptors and plasma membrane receptor on the GIT, from result of interaction it is the STPs and MCT components which mainly regulate response, binding effect was additive, (Figure 1) it is well established that ECM cascade have direct bearing on cellular and nuclear cascades, of course the contribution of binding at cell membrane as describe by mass occupancy theory, $\mathrm{RR}, \mathrm{R}^{\star} \mathrm{R}^{\star}$ state theory to seven response is acknowledged, which is why number of activated STP $\left(N_{i}\right)$ is derived as

\section{$\mathrm{N}_{i}=\left(\mathrm{N}_{\varkappa}-\mathrm{M}_{e f}\right)+\left(\mathrm{N}_{\varkappa}-\mathrm{M}_{a f}\right) \mathrm{N}_{\varkappa} \times \mathrm{L}_{N R}-\sum \mathrm{N}_{L R 1}-\mathrm{Pr}_{p b}+\mathrm{Pr}_{s b} \times \mathrm{N}_{c o}$}

Indeed, it is not contestable that autonomic drugs or the extract bind to three types of receptors,, (1) those that penetrate membrane with or without intrinsic enzymatic activities (2) those couple intercellular such as gtpase binding receptor or G-protein receptors (3) those found intracellular and in the nucleus or on each STP cascade component binding site, adrenaline, acetylcholine and extract acted through adrenergic receptors to activated first part of STPs via Ga (Gs, Gaq, Ga12, Ga13, Ga15, Ga16, Gai, Gao, Gaz, Gat, Gagust) to activate PLC/cAMP/IP3/DAG/calcium/CMLK pathways which open up calcium store and mediate local and globalised calcium actions leading to motility. Again, $\mathrm{Ca}^{2+}$ during bioassay also act on phosphorylase kinase which activate phosphorylase or calmodulin kinase to mediate synaptic junction (secretion of neurotransmitters etc.) or through calmodulin kinase III to cause protein synthesis or through calcinurin which is probably implicated in relaxation of the biomarker, since calcinurin a phosphate has been implicated in inactivating $\mathrm{Ca}^{2+}$ channels by dephosphorylation, also efflux and influx of calcium is determined by $\mathrm{Ca}^{2+}-\mathrm{H}^{+}$exchanger, intracellular release from endoplasmic reticulum through rynadone receptor is mediated by cyclic adenosine diphosphate ribose (cADPR) also calcium act on ras super family (any one Rho, Ran, Rheb, Rad, Rit) and various kinases through signals and activated Raf/ ERK/PKA/MPAK/ other pathways are MEKK 2,3 Tpl2/MEK5/ERK5/ BMK,1 cascades, and MAPKKK/MAPKK/MAPK/ pathways, followed by biological response which is the contraction of the isolated rabbit ileum, again mathematically determined result of Rsm, Nc1, and Tf are conssitance with above observations shown by other findings, it crucial to state that STPs usually act in interconnected fashion and not in isolation, so that other localized processes (circulation, growth of epithelial cells, drug metabolism, immunoreactivity, secretion etc.) on the isolated rabbit ileum were up regulated or down regulated, the extract interaction is the hallmark of the finding in that not only are STPs and MCT implicated in changes in height of contraction but also by acetylation, phosphorylation, receptor internalization, protein modulation of various cascades component lead to the following process circulation, growth of epithelial cells, drug metabolism, immunoreactivity, secretion, we deduced that motility observed caused secretion of GIT peptide hormones, importantly beside these signaling molecules, the extract molecules no doubt bind to other non autonomic receptor thereby besides motility, mediate processes of circulation, growth of epithelial cells, drug metabolism, immunoreactivity, and secretion, few among the cascade actually activated these processes by membrane activation, translocation, activation of transformational changes, agonist activation, and then by phosphorylation, as values for transduction per unit time showed, generally in double and triple interactions, and at moderate concentration, extract did not affect the action of drug, however at high concentration parasympathetic effect of acetylcholine was inhibited by Duranta repens. and sympathetic effect of adrenaline was overcome by Senna obtusifolia at standard deviation 2.28 , height was $1.1 \mathrm{~cm}$ as against $0.9 \mathrm{~cm}$ when adrenaline was added alone, on the whole Duranta repens in group A caused relaxation of ileum (height 0.1 and standard deviation 4.11), in group 3 result, mainly decrease in contraction was seen at high concentration, these events can be accounted for looking at the following; transduction time, cascade recruitments, localized cascade components, waves amplitude of docking sites of adaptar proteins, 'on' and 'off' mode of the STP switches as shown below, for theory like mass occupancy which consider event at binding sites not sufficient to explained theses variations, the fundamental determinants of changes or STPs responses per say are interaction of cascade component note that Rsm for group $\mathrm{C}$ show increase in activities per unit transduction time, first at individual level and then at global level of their interconnected network, thus any of the processes (or STP responses number or magnitude) is function of STPs and MCT to a larger degree, and to a limit degree binding at plasma membrane, for in GIT secretion process, motility was the source of stimulus which by STPs activate secretory cell, latter release signaling molecules in the isolated rabbit ileum, the signaling molecules (motilin, substance $\mathrm{P}$, VIP, secretin etc.) in turns act on various receptors or ion channels to activate many STP, example $\mathrm{Ca}^{2+} / \mathrm{PKC} / \mathrm{Ras} / \mathrm{cRaf} / \mathrm{MEk} 1 / 2 /$ ERK pathways was activated by calcium channels, cytokines and even GPCR serve as stimulus activating MLK3/TAK/DLK/MKK3/6/P38/ MAPKa/ MAPK $\beta / M A P K \gamma$, or through A Raf/B-Raf/c-Raf/Mos/Tpl2/ MEK1/3/ERK to cause growth and differentiation of epithelial cells, the extract molecules or the GIT signaling molecules from luminal secretions response, presumably, activate GIT epithelial cells growth by protein synthesis via RTK, integrin and cytokines receptors, the underlining signaling processes are fak/p3/akt/mtor/ mtor the last cascade component activated transcriptional factors and protein synthesis, so that all the GPRC, RTK and intergrin signals converge

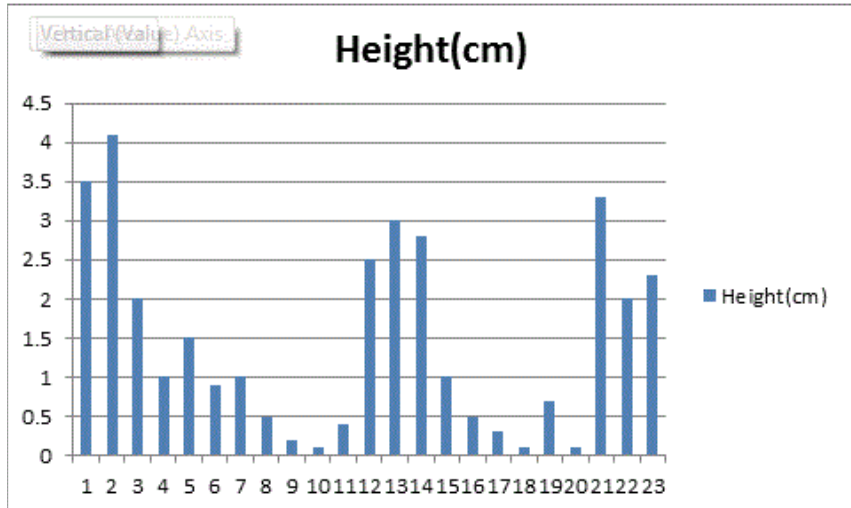

Figure 1: Graph of height of contraction of isolated rabbit ileum smooth muscle in centimetre. 
on akt, pok1 and pip2 kinase, in both kinase pten, PP2A phosphtase regulate progression of the signals, and AKT/raf1/ERK/p70S1k cascades activate luminal epithelial cell growth, if it were not so absence of receptor would have made impossible subsequent interaction of drug while the expirement last, mathematical prove below is consistence with these result of past findings group $C$ Rsm are $46.667^{\wedge} 3,39.203^{\wedge} 8$, $39.203^{\wedge} 8,14.737 \wedge 3,61.536^{\wedge} 5$, all show increase activity per active components per cascade (perhaps the critical points), another processes which depend on STPs and MCT is circulatory processes, in spite that it was isolated, atypical contraction which decreases progressively aided circulation of blood through RTK/AKT//eNOS/NO pathways, see graph below on deactivation of components (point of crossing between black line and blue line), findings show that the secreted GIT signaling molecules have cardiovascular effects for the diffuse from luminal cell to nearby blood vessels, again antigenic reactions at luminal border cannot be rule out, sources of antigen could be drug, extract, or content of organ bath, thus owing to immunoreactivity, I anticipated activation of Toll pathway, IMD pathway and JAK/STAT pathway and so on, this is true looking at Rsm values from group $\mathrm{C}$ and their corresponding $\mathrm{Nc} 1$ values in Tables 3 and 4 below. At moderate concentration $(10 \mathrm{mg} /$ $\mathrm{ml})$ and high volume $(0.8 \mathrm{ml})$ it is clear that if by occupancy theory drug with high affinity binds and occupy available autonomic receptors, then etract molecules bind to other non autonomic receptors, besides hydroxylation affect or other extracts molecular changes caused by methanolic or ethanolic molecules may have affected rate of extract molecule permeability through the membrane such that direct binding between extract molecules and cascade components occurred leading to increase in Rsm values. Note that values of height for group C was not consistence with Rsm values or Nc1, which means that some STPs were inactivated, in graph 2 below, at some point the blue curve turns left and descend a bit, which show that Rsm had remained constant and the decreases slightly at $10 \mathrm{mg}$ of $0.8 \mathrm{ml}$ of extract and cabachol.

Findings reported that these pathways are active in antigenic attack, additionally, local immune response may have been activated by MLK3/TAK/DLK/MKK3/6/p38/MAPK or MEKK/MLK3/ASK1/ MKK/SAPK/JNK cascades, the immune response protected the GIT luminal lining from organ bath pathogenic onslaught if it were not so result of group 3 would have bens same for the drug used were not antipathogens, thus extract lowers contractile effects of the drugs, from $6.4 \mathrm{~cm}$ to $0.1 \mathrm{~cm}$ with each increase in dose for the greoup, standard deviation minimum is 0.21 and maximum is 5.05, again were it not for immunoreactive response the isolates ileal cells would have been killed by pathogenic poison making it useless while before the experiments begins, but that was not the case, again immunoreactivity interaction between the following STP components p21 activated kinase (PAK) which mingle with exchange factor and $G$ protein couple receptor kinase factor, the activated Rac and CdC42 GTPase by manner of PAK and $\mathrm{G}$ protein recruit activator PIX, another recruited protein is a scaffolding protein called GIT, findings SHOWS that integrin and PAK/ $\mathrm{PIX} / \mathrm{GIT} /$ model can act non redundantly in regulating other pathways, perfect correspondence between values of $\mathrm{Ncl}$ and Rsm support these result of action of these characterized proteins.

Proximal GIT coluumnat epithelium contain high qxidative conjugates and hydrolytic drug metabolizing cyp450s enzymes, mdricyp3a4, mpr2, ugt have synergic roles work on them is ongoing, also in GIT metabolism, transcription facto nf-e2 related factor 2(nrf2) is activated in presence of reactive species like superoxide or trioxygen, it sense cysteine residue which is modified by toxic chemical of xenobiotic metabolism, result of other findings show that it has protective effect on GIT metabnolism, with jun, fos and maf, they interact to mediate transcription, also the interact with glutanthion synthase to synthesize GSH which have protective ability against biotransfromed radical in GIT, the findings are consistence with our observation that the isolated rabbit ileum died some hours afer the experiment starts, looking at the graph of Rsm and height of contraction decrease correspond to height, not until deactivated STPs of set in, drug used were certainly metabolized, we could not show which STPs was involved, nevertheless result from calculation supported this assertion, we suspected that drug metabolism play part in slowing down responsiveness and initiating death of isolated rabbit ileum owing to exhausted load of nrf2, thus metabolism is factor of STP and MCT given their roles as shown by Rsm values, for mathematical determination shows that beside motility other processes might have occurred, findings shows that motility may mediate secretion and products of secretion could serve as signal to other GIT events, example motilins and sceretin are implicated in GIT processes of contraction, the fact of occurrence of above processes and their dependence on STPs was reinforce from Ni values, and magnitude of response (Rsm), which was high enough to show that other responses occurred, and that, they are the sole making of STP component mainly, events at binding site play only contributory role.

\section{Mathematically Proved}

Deductively and inductively, we determine binding time, and number of couple receptor, the flux time and other attribute which enable determination of various STPs involved, STPs proteins with low copies for detection can be known mathematically, since product of their action like wave or flux can be measured. Also Probe use is highly specific, again safety lies in knowledge of globalised action of each STP components, which can never be attained without mathematics and quantum physics.

I determined from the organ bath the effects of varying, volume,

\begin{tabular}{|c|c|c|}
\hline Group C tripple combination interaction & Height $(\mathrm{cm})$ & Standard Dev \\
\hline $\begin{array}{c}2 \text { ext } 10 \mathrm{mg} / \mathrm{ml} \text { of } 0.8 \mathrm{ml} \text { and ach } 2 \mathrm{ug} \text { of } 0.4 \\
\mathrm{ml}\end{array}$ & 6.4 & 1.85 \\
\hline $\begin{array}{c}2 \mathrm{ext} 100 \mathrm{mg} / \mathrm{ml} \text { of } 0.4 \mathrm{ml} \text { and ach } 2 \mathrm{ug} \text { of } \\
0.4 \mathrm{ml}\end{array}$ & 0.6 & 1.42 \\
\hline $\begin{array}{l}2 \text { ext } 100 \mathrm{mg} / \mathrm{ml} \text { of } 0.4 \mathrm{ml} \text { and ca } 0.5 \mathrm{ug} \text { of } \\
\qquad 0.2 \mathrm{ml}\end{array}$ & 0.3 & 2.55 \\
\hline $\begin{array}{c}2 \text { ext } 10 \mathrm{mg} / \mathrm{mlof} 0.8 \mathrm{ml} \text { and ca } 0.5 \mathrm{ug} \text { of } 0.2 \\
\mathrm{ml}\end{array}$ & 4 & 1.15 \\
\hline $\begin{array}{c}2 \text { ext } 10 \mathrm{mg} / \mathrm{ml} \text { of } 0.8 \mathrm{ml} \text { and Phys } 2 \mathrm{ug} \text { of } \\
0.25 \mathrm{ml}\end{array}$ & 2 & 0.21 \\
\hline $\begin{array}{l}2 \text { ext } 100 \mathrm{mg} / \mathrm{ml} \text { of } 0.4 \mathrm{ml} \text { and phys } 2 \mathrm{ug} \text { of } \\
0.25 \mathrm{ml}\end{array}$ & 0.2 & 3.35 \\
\hline $\begin{array}{l}2 \mathrm{ext} 10 \mathrm{mg} / \mathrm{ml} \text { of } 0.8 \mathrm{ml} \text { and A DR } 10 \mathrm{ug} / \mathrm{ml} \\
\text { of } 0.2 \mathrm{ml}\end{array}$ & 0.1 & 5.05 \\
\hline
\end{tabular}

Table 3: Shows result of triple interaction between drug and extract Ext: extract, Phys: physostigmine.

\begin{tabular}{|c|c|c|c|c|}
\hline dr and ext & Rsm & Height & Conc (vol) & Nc1 \\
\hline S O+ca & 27.996 & 6.5 & $10 \mathrm{mg}(8 \mathrm{ml})$ & $0.7 \mathrm{~s}$ \\
\hline S O+ach & 54.949 & 6.5 & $10 \mathrm{mg}(8 \mathrm{ml})$ & $0.6 \mathrm{~s}$ \\
\hline D R+adr & 14.499 & 1 & $10 \mathrm{mg}(8 \mathrm{ml})$ & $0.3 \mathrm{~s}$ \\
\hline S O+Adr & 12.509 & 1.1 & $10 \mathrm{mg}(0.2 \mathrm{ml})$ & $0.4 \mathrm{~s}$ \\
\hline dr and ext & $\mathbf{R s m}$ & Height & Conc $(\mathbf{v o l})$ & Nc1 \\
\hline 2 ext+ach & $46.667^{\wedge} 3$ & 6.4 & $10 \mathrm{mg}(0.8 \mathrm{ml})$ & 1 \\
\hline 2 ext+ca & $39.203^{\wedge} 8$ & 4 & $10 \mathrm{mg}(0.8 \mathrm{ml})$ & 0.6 \\
\hline 2 ext+adr & $14.737^{\wedge} 3$ & 0.4 & $10 \mathrm{mg}(0.8 \mathrm{ml})$ & 0.5 \\
\hline 2 ext+phys & $61.536^{\wedge} 5$ & 2 & $10 \mathrm{mg}(0.8 \mathrm{ml})$ & 0.4 \\
\hline
\end{tabular}

Table 4: The comparative results of magnitude of STP response (Rsm) and flux time per unit critical component of STPs cascade. 
concentration of drugs/extracts using certain parameter such as terminal speed of the molecules, stokes law, volumetric analysis parameters, firstly, to know the time either extract or drug or putative probes bind with receptor and the time the STPs backbone and the ones linked to it was activated, subsequently I determine the responses time taking into cognizance the time contraction or relaxation of the ileum starts, fortuitously, these novel approach indicated at what volume or concentration of molecules (drug or even probes) maximal or minimal response occurred.

From molecular kinetic Total number of molecules $N_{x}$ towards $\times$ direction is given by $\underline{1 \times \boldsymbol{N} \times \boldsymbol{A d}}$ obtained from gas molecules kinetics.

Where Ad volume of the organ bath,

Thus similarly $N_{x}$ values for other extract and drug was were determined, and so $N_{x}$

Alone $\mathrm{S}=1.56 \times 10^{6}, \mathrm{D}=3.12 \times 10^{6} \mathrm{Ach}=1.61 \times 10^{6}$, physostigmine $=4.6$ $\times 10^{6}, \mathrm{Nico}=2.8 \times 10^{6}$, carbachol $=7.6 \times 10^{6}$, adrenaline $=3.8 \times 10^{6}$, atropine $=3.85 \times 10^{6}$,.in two combination $\mathrm{S}+\mathrm{ph}=6.2 \times 10^{6}, \mathrm{~S}+\mathrm{Ac}=3.3$ $\times 10^{6}, \mathrm{~S}+\mathrm{Ca}=9.2 \times 10^{6}, \mathrm{D}+\mathrm{Ad}=7 \times 10^{6}, \mathrm{~S}+\mathrm{at}=5.4 \times 10^{6}, \mathrm{~S}+\mathrm{Ad}=5.4 \times$ $10^{6}, \mathrm{~S}+\mathrm{D}=4.7 \times 10^{6} \mathrm{~S}+\mathrm{ni}=4.4 \times 10^{6}, \mathrm{D}+\mathrm{ni}=6 \times 10^{6}, \mathrm{~S}+\mathrm{D}+\mathrm{Ad}=9 \times 10^{6}$ $\mathrm{S}+\mathrm{D}+\mathrm{Ph}=9.3 \times 10^{6} \mathrm{~S}+\mathrm{D}+\mathrm{Ac}=6.3 \times 10^{6}, \mathrm{~S}+\mathrm{D}+\mathrm{At}=8.6 \times 10^{6}, \mathrm{~S}+\mathrm{D}+\mathrm{ni}=7.5$ $\times 10^{6}, \mathrm{~S}+\mathrm{D}+\mathrm{Ca}=12.3 \times 10^{6}$

\section{All values are approximated to 6 million (Boy’o) [6].}

First and foremost, I posit that any number or magnitude of response $\left(R_{s}\right)$ is a function of or proportional to activated STP backbones $\left(N_{i}\right)$ and inversely proportional to inactivated STP backbone $\left(N_{y}\right)$

$$
\text { i.e. } R_{s} \propto \frac{N_{i}}{N_{y}} \text { and thus } R_{s}=K \frac{N_{i}}{N_{y}}
$$

$\mathrm{K}$ is a universal constant proportionality of therapy which reflex MCT at unity $\mathrm{K}=1$

\section{Determination of $N_{i}$}

To determine $N_{i}$ I used two methods, the novel one and another novel one which employ the law of mass occupancy theory as well as $\mathrm{R}^{\star} \mathrm{R}, \mathrm{R}^{\star}$, or $\mathrm{R}^{\star} \mathrm{R}^{\star}$ constitutive state theory.

Novel Method one without occupancy or constitutive state theory

$$
\mathrm{N}_{\mathrm{x}} \times \sum \mathrm{N}_{\mathrm{LR} 1}-\left\{\mathrm{Pr}_{\mathrm{pb}}+\mathrm{Pr}_{\mathrm{sb}}\right\} \times \mathrm{N}_{\mathrm{co}} \times{ }_{\mathrm{n}} \mathrm{E}=\mathrm{N}_{\mathrm{i}}(2)
$$

Where $N_{c o}$ denote number of receptors types coupled to transmembrane to receptors and effector. Generally, research show that Five known basic GIT receptors; GPCRs, guanylyl kinase (GK), Tyrosine kinase (TK), Cytokine kinase (CK) and Ionic channels (IC) are all couples or attached respective to $5 \mathrm{G}$ protein, 1 kinase, 1 kinase, 1 kinase, and 1 channels meaning that there are $9 N_{c o}$ but in contraction of the ileum, for two or more combinations and $7 N_{c o}$ for contraction (stimulatory response) and $6 N_{c o}$ for relaxation (inhibitory response) and $N_{L R}$ terms means sum of all the receptors in locus 1, 2, or 3 (Boyo 2014) and thus $N_{L R 1}$ means sum of all receptors in locus 1 given by my novel formula $\mathrm{Z}_{\mathrm{o}}+\mathrm{n}+V=N_{L R I}\left(\mathrm{Z}_{\mathrm{o}}=\right.$ no of free ECM fluid cells receptors, $\mathrm{V}=$ no receptors free ECM cells, $\mathrm{n}=$ the values are determined mathematically or experimentally (see general derivation of vital parameters I advocated for below), $\operatorname{Pr}_{\mathrm{pb}}+\mathrm{Pr}_{\mathrm{sb}}$ denote sum of respective probability of molecules binding to protein (e.g. albumin) or any structure not involve in activation, they are determined experimentally and $\mathrm{nE}$ is the number of initial effectors, therefore number of STPs backbone or main pathways $\mathrm{N}_{\mathrm{i}}$ for drug/extract added, We assumed that all molecules have equal chance of binding, molecules with affinity and efficacy were not considered because aside other binding which do not involve receptors $-\left\{\mathrm{Pr}_{\mathrm{pb}}+\mathrm{Pr}_{\mathrm{sb}}\right\}$ definitely binding of all kinds ultimately activate the coupled receptor or ionic channels or transporters as the case may be, each of which in turn activate effectors linked to STP backbone or main pathways and that's why everything was multiply by $N_{c o}$ to get $N_{i}$ in equation 2 above.

\section{From extract}

Assuming that $\mathrm{N}_{\mathrm{LR} 1}$ values are known experimentally (see relevant database) let just use $30000 \times 10^{15} 40000 \times 10^{16}$ and $30000 \times 10^{10}$ respectively for $Z_{o}, \eta$, and $V$, their sum $=4.300003 \times 10^{20} N_{x}$ then we can determine the probability ( $\mathrm{Pr}$ ) of binding for $\mathrm{pb}$ and sb i.e. for $\operatorname{Pr}(p b 1$ or $p b 2 \ldots \ldots)=P(P b 1)+P(p b 2) \ldots+\operatorname{Pr}\left\{\frac{\boldsymbol{p b} 1}{\boldsymbol{p b} 2}\right\} \ldots$, let say that sum values each $\mathrm{pb}$ and $\mathrm{sb}$ are 5.001 and 8.033 respective

Value $\mathrm{N}_{\mathrm{LR} 1}=4.300003 \times 10^{\wedge} 20$

$\mathrm{N}_{\mathrm{co}}=7$

$\mathrm{N}_{\mathrm{x}}$ for Extract $=1.56 \times 10^{\wedge} 37$

And so using $\mathrm{N}_{\mathrm{i}}=\mathrm{N}_{\mathrm{x}} \times \sum \mathrm{N}_{\mathrm{LR} 1}-\mathrm{Pr}_{\mathrm{pb}}+\mathrm{Pr}_{\mathrm{sb}} \times \mathrm{N}_{\mathrm{co}} \times{ }_{\mathrm{n}} \mathrm{E}$

$\mathrm{N}_{\mathrm{i}}=1.56 \times 10^{6} \times 4.300003 \times 10^{20}-5.001+8.033 \times 7 \times 3=4.69 \times 10^{6}$ STPs per locus one,

Note that desired each values $Z_{0}, \eta$ and $V$ of $\sum N_{L R 1}$ can be subtracted in evaluation to get respective STP i.e. per free cells, per ECM structure per fluid receptors respectively.

Therefore using same methods Ni for other drugs and extract includes:

$\mathrm{S}=4.69 \times 10^{6}, \mathrm{D}=9.38 \times 10^{6} \mathrm{Ach}=7.85 \times 10^{6}$, physostigmine $6.46 \times$ $10^{6}$, nicotine $=8.65 \times 10^{6}$, carbachol $=4.6 \times 10^{6}$, adrenaline $=2.32 \times 10^{6}$, Atropine $=1.16 \times 10^{6}, \mathrm{~S}+\mathrm{Ach}=12.6 \times 10^{6}, \mathrm{~S}+\mathrm{ph}=11.2 \times 10^{6}, \mathrm{~S}+\mathrm{ni}=13.3$ $\times 10^{6}, \mathrm{D}+\mathrm{ni}=18 \times 10^{74}, \mathrm{~S}+\mathrm{ca}=9.2 \times 10^{\wedge} 6, \mathrm{~S}+\mathrm{at}=5.9 \times 10^{6}, \mathrm{~S}+\mathrm{ad}=7 \times$ $10^{6}, \mathrm{D}+\mathrm{ad}=11.7 \times 10^{6}, \mathrm{D}+\mathrm{ni}=18 \times 10^{6}, \mathrm{~S}+\mathrm{D}=14 \times 10^{6}, \mathrm{~S}+\mathrm{D}+\mathrm{ad}=16.3$ $\times 10^{6}, \mathrm{~S}+\mathrm{D}+\mathrm{Ph}=20 \times 10^{6}, \mathrm{~S}+\mathrm{D}+\mathrm{ac}=21.9 \times 10^{6}, \mathrm{~S}+\mathrm{D}+\mathrm{at}=15.2 \times 10^{6}$, $\mathrm{S}+\mathrm{D}+\mathrm{ni}=22.7 \times 10^{6}, \mathrm{~S}+\mathrm{D}+\mathrm{ca}=18.6 \times 10^{6}, \mathrm{STP}$ s backbones or main pathways respectively.

In the bioassay beside motility about four other responses occurred, metabolism, absorption, secretion, proliferation of the epithelial cells, number of motility, thus whether $\mathrm{R}^{*}, \mathrm{RR}^{*}, \mathrm{RR}$ exist or not response magnitude occur by many actions of STP component, such as critical points, recruitment, phosphorylation, acetylation, recruitment, and so on which the relation $\frac{\left(C_{p}+P_{f}+P D\right)^{n}}{\sum}$ in equation 6 attempt to capture for any given body process $\sum_{n=1}$ or $3 N_{\text {g }}$ manitude of response emanating from backbone cascades., which was why I used the coupled receptor and note that two method were used for $\mathrm{Ni}$ determination beside equation 2 , another novel method which incorporate law of mass actions and $R^{\star} R, R^{\star} R$, etc. was used see equation 3 below.

$$
N_{i}=\left(N_{x}-M_{e f}\right)+\left(N_{x}-M_{a f}\right) N_{x} \times L_{N R}-\sum N_{L R I}-P r_{p b}+P r_{s b} \times N_{c o} \text { (3) }
$$

Where $M_{e f}$ is number of molecules with affinity and $M_{a f}$ is the number of molecules with efficacy as determined experimentally or from mass occupancy theory, with known values of other variable as determined in equation 2. $\mathrm{N}_{\mathrm{i}}$ Can be known.

From equation 1 above $R_{s}=K \frac{N_{i}}{N_{y}}$ 
We incorporate $\mathrm{Ni}$, initially $\mathrm{Ni}$ from equation 2 and 3.

From equation 2: $\mathrm{N}_{\mathrm{x}} \times \sum \mathrm{N}_{\mathrm{LR} 1}-\left\{\mathrm{Pr}_{\mathrm{pb}}+\mathrm{Pr}_{\mathrm{sb}}\right\} \times \mathrm{N}_{\mathrm{co}} \times{ }_{\mathrm{n}} \mathrm{E}=\mathrm{N}_{\mathrm{i}}$.

Substitute equation 2 in 1 above we have.

${ }_{\boldsymbol{R}_{s}=\boldsymbol{K} \frac{\left(\boldsymbol{N}_{x} \times \sum \boldsymbol{N}_{L R 1}-\left\{\boldsymbol{P r}_{p b}+\boldsymbol{P r}_{s b}\right\} \times \boldsymbol{N}_{c o} \times \boldsymbol{n E}\right)}{\boldsymbol{N}_{y}}}^{\text {Determination of } \mathbf{N y}}$

We employ concept of quantum physics, here we assumed each component to behave as wave and particles, before then we employ transduction time at critical point $(\mathrm{CP})$ divide by magnitude or strength of the field due to electrical activities gives strength of each flux branching out from the critical points thus $\mathrm{CP} / \mathrm{E}$, so that the range of values obtained to the power of flux velocity emanating from critical points to know changes $\mathrm{CP} / \mathrm{E}$ caused flux velocity, thus $\mathrm{V}_{\mathrm{i}}^{\mathrm{CP} / \mathrm{E}}$, note that $\mathrm{V}_{1}$ is flux velocity per unit cascade, But for component that are not critical points, we determine how transduction time per unit component changes flux velocity per unit component $V c^{n t}$ where $\mathrm{Vc}$ is velocity per cascade component and nt transduction time per cascade component, thus

$\mathrm{Ny}=\mathrm{V}_{\mathrm{i}}^{\mathrm{CP} / \mathrm{E}} \mathrm{xV}_{\mathrm{c}}^{\mathrm{rt}}$ substitute in equation 1.

Thus

$\boldsymbol{R}_{s}=\boldsymbol{K} \frac{\left(\boldsymbol{N}_{\boldsymbol{x}} \times \sum \boldsymbol{N}_{\boldsymbol{L} \boldsymbol{R} 1}-\left\{\boldsymbol{P r}_{\boldsymbol{p b}}+\boldsymbol{P} \boldsymbol{r}_{s \boldsymbol{b}}\right\} \times \boldsymbol{N}_{c o} \times \boldsymbol{n E}\right)}{V_{l}^{C P / E} V c^{n t}}$

In the limit as signal tend to zero $\mathrm{Ny}=\mathrm{V}_{\mathrm{i}}^{\mathrm{CP} / \mathrm{E}} \times \mathrm{V}_{\mathrm{c}}^{\mathrm{rt}}$ cancels out

And therefore

$\mathrm{R}_{\mathrm{s}}=\mathrm{K}\left(\mathrm{N}_{\mathrm{x}} \times \sum \mathrm{N}_{\mathrm{LR} 1}-\left\{\mathrm{Pr}_{\mathrm{pb}}+\mathrm{Pr}_{\mathrm{sb}}\right\} \times \mathrm{N}_{\mathrm{co}} \times{ }_{\mathrm{n}} \mathrm{E}\right.$

But response depends on critical points, recruitment of several peripheral factors and wave nature of STPs, transduction per unit time per unit component, flux per unit component, we introduced the following into equation 1 ; $\mathrm{Cp}, \mathrm{Pf}, \mathrm{PD}, \mathrm{tf}, \mathrm{av}, \mathrm{Nc1}$

$$
\begin{aligned}
& \text { And thus } \mathrm{R}_{\mathrm{s}}=\mathrm{K}\left(\mathrm{N}_{\mathrm{x}} \times \sum \mathrm{N}_{\mathrm{LR} 1}-\left\{\operatorname{Pr}_{\mathrm{pb}}+\mathrm{Pr}_{\mathrm{sb}}\right\} \times \mathrm{N}_{\mathrm{co}} \times{ }_{\mathrm{n}} \mathrm{E}\right. \\
& \frac{\left(\boldsymbol{C}_{\boldsymbol{p}}+t f+V l+N_{c 1}\right)^{\sum n 1-n 2}}{\sum_{n=1,2,3 .} n N_{o} N e c}
\end{aligned}
$$

To assuage the yearning of proponents of mass occupancy theory or $R R, R^{\star}, R^{\star} R^{\star}$ concepts We use equation 3 in equation 6 instead equation 2 and thus from equation 3 .

$$
\boldsymbol{N}_{i}=\left(\boldsymbol{N}_{x}-\boldsymbol{M}_{e f}\right)+\left(\boldsymbol{N}_{x}-\boldsymbol{M}_{a f}\right) \boldsymbol{N}_{x} \times \boldsymbol{L}_{N R}-\sum \boldsymbol{N}_{L R 1}-\boldsymbol{P r _ { p b }}+\boldsymbol{P r _ { s b }} \times \boldsymbol{N}_{c o}
$$

Therefore:

$$
\begin{aligned}
\boldsymbol{R}_{s}=\boldsymbol{K}\left(\boldsymbol{N}_{x}-\boldsymbol{M}_{e f}\right)+\left(\boldsymbol{N}_{x}-\boldsymbol{M}_{a f}\right) \boldsymbol{N}_{x} \times \boldsymbol{L}_{N R}-\sum \boldsymbol{N}_{L R 1}-\boldsymbol{P} \boldsymbol{r}_{p b}+\boldsymbol{P} \boldsymbol{r}_{s b} \\
\times \boldsymbol{N}_{c o} \frac{\left(\boldsymbol{C}_{p}+t f+V l+N_{c 1}\right)^{\sum n 1-n 2}}{\sum_{n=1,2,3 .} n N_{o} N e c}
\end{aligned}
$$

Definition of term

$R_{s}=$ STPs and MCT responses or body processes,

$\mathrm{t}_{\mathrm{f}}=$ flux time per unit cascade backbone,

$a_{v}=$ flux velocity of each STPs component,

$\mathrm{N}_{\mathrm{cl}}=$ flux velocity of each STP backbone activated,

$\mathrm{V}_{\mathrm{i}}=$ flux velocity per unit component,
$\mathrm{K}=\mathrm{is}$ a constant proportionality which is the Molecular cross talk (MCT),

$$
\frac{\left(\boldsymbol{C}_{p}+t f+V l+N_{c 1}\right)^{\sum n 1-n 2}}{\sum_{n=123} n N_{o} N e c}=\text { implies rate of monomial expansion }
$$
(branching) of cascade for one STP components example $C_{p}$, binomial expansion (branching) of cascade example for two components $\left(C_{p}\right.$, $\mathrm{t}_{\mathrm{f}}$ ) or polynomial expansion (branching) of cascade example for three STPs components $\left(C_{p}, \mathrm{t}_{\mathrm{f}}, \mathrm{V}_{\mathrm{i}}, \mathrm{N}_{\mathrm{cl}}\right)$ streams, components may be kinases or other protein types, raise to $\mathrm{n}, \mathrm{n}$ could $\mathrm{PF}$ or $\mathrm{PD}, \mathrm{n} 1$ is activating event at each component, where as $\mathrm{n} 2$ is deactivating events, $\mathrm{n} 1$ or $\mathrm{n} 2$ can be express in particulate nature or wave nature (the quantum factor) example $\mathrm{n} 1$ particulate nature $=$ phosphorylation at binding site derivable from $\mathrm{Pc}$ and $\mathrm{Pf}$ equation 10 and 11, n1 wave form is nature of wave flux generated by two or more interacting STPs components derivable from PD equation 9, is divided by sum of one or more number of activated STP backbone ( $\mathrm{n} \mathrm{No}$ ), note all the equation are subject to calculus derivation, and again from binomial expansion

$$
\begin{aligned}
& (x+a)^{n}=\sum_{k=0}^{n}\left(\begin{array}{l}
n \\
k
\end{array}\right) x^{k} a^{n-k} \\
& \text { or }(\mathrm{a}+\mathrm{b})^{\mathrm{n}}=\mathrm{a}^{\mathrm{n}}+\mathrm{n}_{\mathrm{C} 1} \mathrm{a}^{\mathrm{n}-1} \mathrm{~b}+\cdots+\mathrm{n}_{\mathrm{Cr}}, \mathrm{a}^{\mathrm{n}-\mathrm{r}} \mathrm{b}^{\mathrm{r}}+\cdots+\mathrm{b}^{\mathrm{n}} \\
& \text { Where } \boldsymbol{n}_{c_{r}}=\frac{\boldsymbol{n} !}{(\boldsymbol{n}-\boldsymbol{r}) ! \boldsymbol{r} !}
\end{aligned}
$$

and again equation 7 and 8 though in binomial form must be change to polynomial or even monomial form, depending on cascade event under consideration, these equation and advance calculus can be used to derived vital relation for each component or many component of the expanding chains of cascades, for by their amplification, they expand the signals and the magnitude of the signal depends on their expansion.

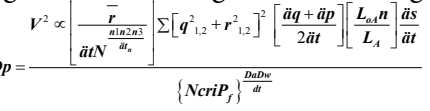

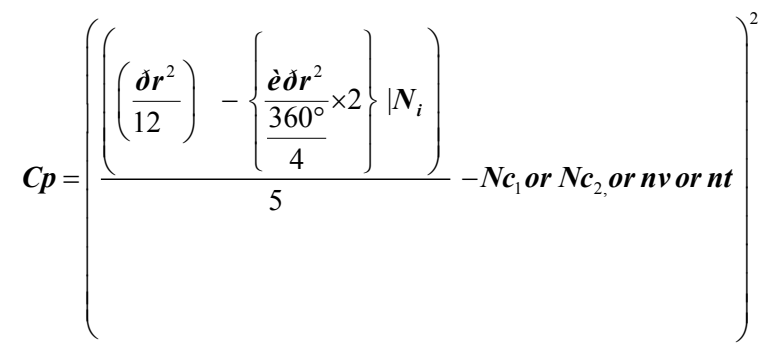

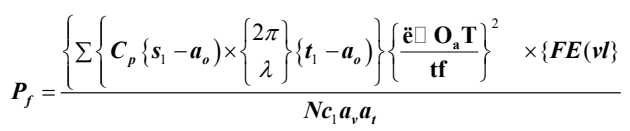

The detail of derivation of equation 9,10 and 11 is given in boyo's work which borders findings on indirect role of STP on contractility of GIT. (Boy'o 2014).

In the bioassay, beside motility other responses occurred, metabolism, absorption, secretion, proliferation of the epithelial cells which were not recorded can be ascertain with aid of graph of $\mathrm{Ni}$ vs. Rs, and Rs vs. Height of contraction (H), we use $\mathrm{H}$ from group 2 and 3 result. 
So we determine magnitude of response Rsm

From binomial equation, we look at two cases of expansion of cascade component, $\mathrm{Cp}$ and av, we solved for $(\mathrm{a}+\mathrm{b})^{\mathrm{n}}$ i.e. $(c p+a v)^{\mathrm{pf}}$ from group B result Senna obtusifolia and cabachol (ca) Senna obtustifolia and acetylcholine (ach), Duranta repens and Adrenaline (adr), Senna obtustifolia and adrenalin (adr) thus.

But from Binomial series

$$
(\boldsymbol{a}+\boldsymbol{b})^{\boldsymbol{n}}=\boldsymbol{a}^{\boldsymbol{n}}+\boldsymbol{n}_{c_{1}} \boldsymbol{a}^{\boldsymbol{n}-1} \boldsymbol{b}+\ldots+\boldsymbol{n}_{c_{r}} \boldsymbol{a}^{\boldsymbol{n}-\boldsymbol{r}} \boldsymbol{b}^{\boldsymbol{r}}+\ldots+\boldsymbol{b}^{\boldsymbol{n}}
$$

For Senna obtusifolia and ca, av=4.9, $c p=11.1 \times 10^{6}$

Thus

$$
\begin{gathered}
(\boldsymbol{c} \boldsymbol{p}+\boldsymbol{a} \boldsymbol{v})^{p f}=\boldsymbol{c} \boldsymbol{p}^{p f}+p f_{c_{1}} \boldsymbol{c} \boldsymbol{p}^{p f-r} \boldsymbol{a v}+\ldots+\boldsymbol{p} \boldsymbol{f}_{\boldsymbol{r}} \boldsymbol{c} \boldsymbol{p}^{p f-r} \boldsymbol{b}^{r}+\ldots+\boldsymbol{b}^{p f} \\
\text { Note that } p f_{c_{1}}=\frac{\boldsymbol{p} \boldsymbol{f} !}{(\boldsymbol{p} \boldsymbol{f}-\boldsymbol{r}) ! \boldsymbol{r} !} \text { but } \mathrm{pf}=7.4 \times 10^{55} \text {, taking } \mathrm{r}=6 \mathrm{STP} \\
\text { components thus, }
\end{gathered}
$$

$$
\begin{aligned}
& p f !=\frac{7.4 \times 6.4 \times 5.4 \times 4.4 \times 3.4 \times 2.4 \times 1.4}{12.9-6 ! 6 !}=\frac{12,855.1}{4286.6 \times 720}=\frac{12855.1}{3086352}=0.04165 \times 10^{55} \\
& (\boldsymbol{c p}+\boldsymbol{a v})^{p f}=11.1 \times 10^{6}\left(7.4 \times 10^{55}\right)+\left(0.04165 \times 10^{55}\right)^{\left(7.4 \times 10^{55}-6\right)} \\
& \times 4.9+\left(0.04165 \times 10^{55}\right) 11.1 \times 10^{6\left(7.4 \times 10^{15}-6\right)} \times 4.9^{6}+4.9^{7.4 \times 10^{6}} \\
& (\boldsymbol{c p}+\boldsymbol{a v})^{p f}=\mathbf{1 5 2 1 9 2 . 5}
\end{aligned}
$$

From equation 6 or 7 rate of expansion and combination is

Let sum of number of component per cascades (No) STP components $=10$ and $\mathrm{Nec}=5$,

Thus $\frac{152192.5}{10 \times 5}=\mathbf{3 0 4 3 . 9}$, note for group $3 \mathrm{No}=15, \mathrm{Nec}=8$.

But Ni for for Senna obtusifolia and ca=9.2 $\times 10^{6}$

From equation 2: $\mathrm{N}_{\mathrm{x}} \times \sum \mathrm{N}_{\mathrm{LR} 1}-\left\{\mathrm{Pr}_{\mathrm{pb}}+\mathrm{Pr}_{\mathrm{sb}}\right\} \times \mathrm{N}_{\mathrm{co}} \times{ }_{\mathrm{n}} \mathrm{E}=\mathrm{N}_{\mathrm{i}}$,

And $\mathrm{R}_{\mathrm{s}}=\mathrm{K}\left(\mathrm{N}_{\mathrm{x}} \times \sum \mathrm{N}_{\mathrm{LR} 1}-\left\{\operatorname{Pr}_{\mathrm{pb}}+\mathrm{Pr}_{\mathrm{sb}}\right\} \times \mathrm{N}_{\mathrm{co}} \times{ }_{\mathrm{n}} \mathrm{E}\right.$,

$\frac{\left(\boldsymbol{C}_{p}+t f+V l+N_{c 1}\right)^{\sum^{n 1-n 2}}}{\sum_{n=1,2,3 .} n N_{o} N e c}$ see equation 6 and $\mathrm{K}=1$.

Therefore magnitude of response $R_{s m}$ for senna obtusifolia and

cabachol $=9.2 \times 10^{6} \times 3043.9=27.99652 \times 10^{3}$ for others see Table 4.

Note as far as above result and equations are concerns, a fundamental truth is that drug could be replaced with a probe (both are molecules nonetheless) but probe use need be extremely specific to allow for one to one binding (example probe to rab binding). And with equation 6 and 7, we have shown that anybody processes or STP response is function of activated STPs backbone, it is increase with Ni and decrease with Ny provided K (MCT) remain constant. the values were derived experimentally and inserted into the equation, $R_{s m}$ the magnitude or number of response was determined, and insight from this result manipulated for use in biomedical research, drug development, clinical application and in control and regulation of STPs which BUTT sort, note that further derivative of the equation may be required, STP effects on the waves generated by interstitial cells of cajal lead to increase in intra-cellular concentration of $\mathrm{Ca}^{2+}, \mathrm{Ca}^{2+}$ either through ligand gated or voltage ( $\mathrm{T}$ or $\mathrm{L}$ ) gated enter the cells and bind to calcium binding protein calmodulin which activate myosine dependent kinase such as myosine kinase which phosphorylates myosine and cause contraction, also different forms of agonist/partial agonist (synergism, potentiating) or antagonism (competitive or non competitive equilibrium) interactions activate many receptors which transducer signal and amplify them by STP mechanism, and generate waves of spatio-temporal dynamics actions which in turn amplify the motility response, as deduced from equations below.

Normal body embryological, physiological and biochemical systemic processes and products of none bindings interaction involves STPs (brown boxes), binding relate to body milieu interactions (green boxes) via STP and responses (block and yellow boxes inside the green box) are mediated through STP and in rabbit ileum assay motility, secretion. Immunoreactivity, metabolism etc. are STPs responses, (Figures 2-9).

It crucial to not that determination of some parameter ensures derivation of equations used above few among them are; organ bath concentrations (C2) for each extract and drug used was determined from $\mathrm{C} 1 \mathrm{~V} 1=\mathrm{C} 2 \mathrm{~V} 2$, binding time of the ligand and the flux time which denote the time binding activate STP to the time response was observed, flux time per unit STP components (FTPUSC) i.e. net time it takes for signal to move from one components to another, thus I showed that there are four types, (1) flux per unit critical points, (2) flux per unit peculiar inter STP components, (3) flux per unit peculiar peripheral factor and, (4) flux per unit components of the backbones. Other variable determined are Number molecules, velocity of flux (Vl), number of activated STP backbone ( $\mathrm{Nc1}$ ), also vital parameters includes; total number of receptors express on intracellular (membrane) and extracellular domain, and their respective number of binding site, number and magnitude of charge of sites, number conformational changes after binding and other such parameter relevant to the equation 1 , their determination are detailed in a work which investigate indirect effect of STP mathematically (Boyo 2014).

\section{Conclusion}

It can be concluded, from experimental and mathematical results that height of contraction correspond perfectly with magnitude or response $R_{s m}$, STPs and MCTs control and regulate all processes, they are the basic unit of control and regulation of all processes inclusive of neural and hormonal ones, and thus magnitude of response $R_{s m}$ remains an important attribute of STPs in biomedical research, clinical uses, drug formulation and use, since it relate response to specific and global actual effects of STPs activities which prove BUTT 1. in fact the BUTT concepts wrap in mathematics and quantum physics principles makes possible handling of several complex pathways in several cells, organ or systems for globalised view of STP is fundamental to it exploitation in research.

\section{Future Outlook}

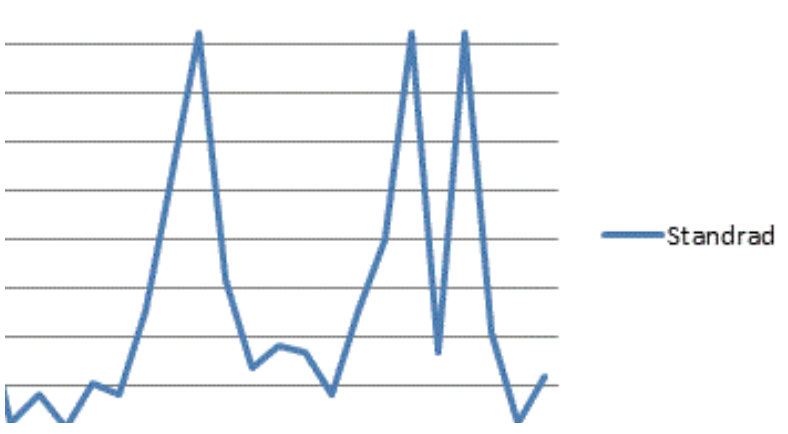

Figure 2: Graph of standard deviation of values of height of contraction of isolated rabbit ileum figures on $X$ axis denotes each case on Table 3 above, $Y$ axis denotes height of contraction. 
Citation: Sani M (2015) Quantum Physics and Mathematical Aided Proof of Theory 1 of Boy'o Universal Theory of Therapy (BUTT) . J Med Diagn Meth S1: 005. doi: 10.4172/2168-9784.S1-005

Discovered cascade and their characterize proteins or enzymes show that biological processes can't do without STP, this constitute a riddle of some sort in the field of biomedical research, the aim of BUTT 1 is to unravel this mystery so that everything about biomedical

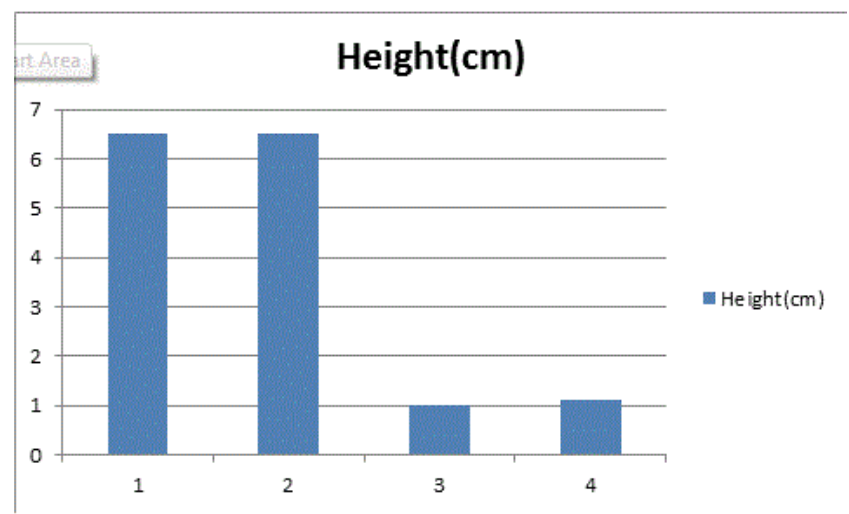

Figure 3: Bar chart of height of contraction against each case as shown in Table 2 above.

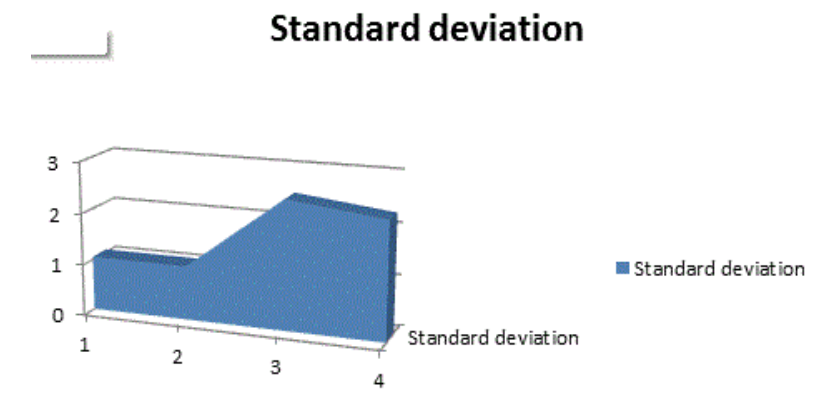

Figure 4: A graph of group $B$ shows height of contraction of isolated rabbit ileum, figures on $X$ axis denotes case wise consideration, $Y$ axis is height of contraction as shown in the Table 2.

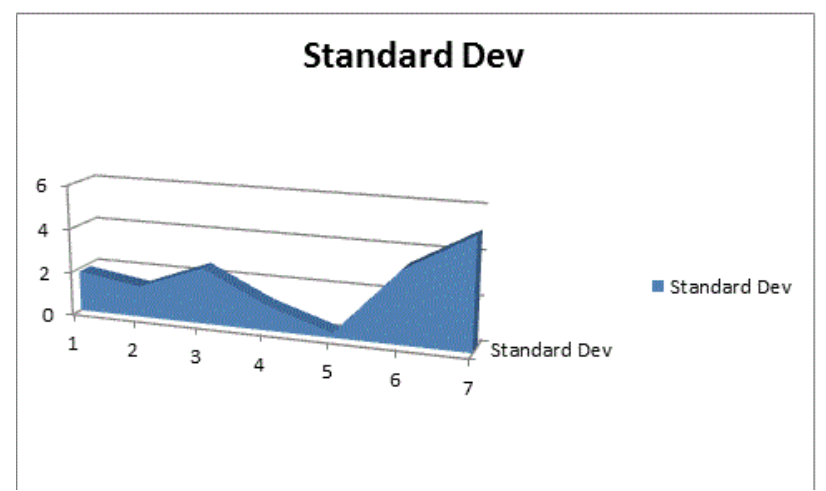

Figure 5: Graph of standard deviation of Table 3 result, figures on $X$ axis denotes case wise consideration, $Y$ axis is height of contraction as shown in the Table 2.

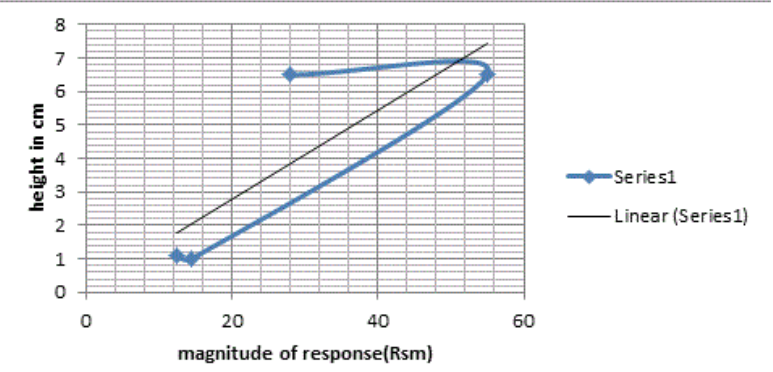

Figure 6: Nc1 vs. Rsm, Note how Rsm depends on Nc1, it means that response is function of STP not just binding events alone, more on STP events than binding between ligand and membrane receptors, this is of clinical, biomedical, biotechnological, and drug use importance, since STP responses are body physiologic, biochemical, genetic, embryologic, metabolic processes in manifestation.

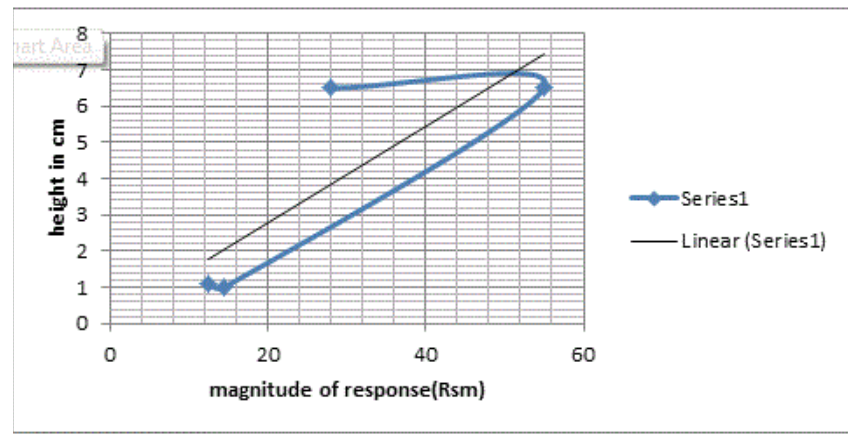

Figure 7: A graph 2 of height vs. Rsm. Increase in height correspond perfectly with increase in Rsm until at certain values for a certain group, meaning that STPs responses or body processes depends on activated STP and inactivated one, from the graph many STP were deactivated at point were black line cross the curve (blue line), such drug molecules are potential target use in enterprise meant to deactivate STP cascade, as in cancer, thus Senna obtusifolia and cabachol molecules are potential candidates for STP deactivation. We again adduced that some extract molecules might have entered the cell membrane to bind with any of the STP, for research show that isoprenylated acetophenone and rosenonolactone are part of active constituent of the extract.

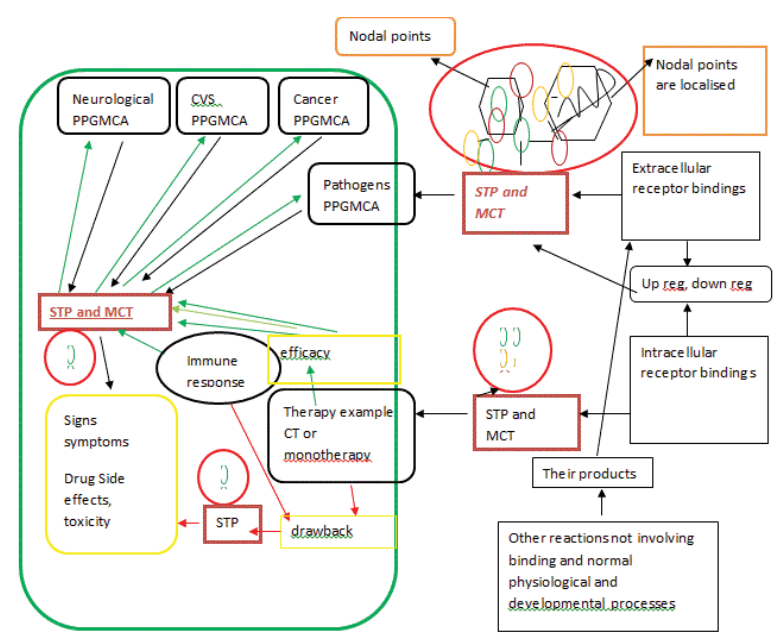

Figure 8: Diagrammatic shows dependent of body processes on STP and MCT. 
Citation: Sani M (2015) Quantum Physics and Mathematical Aided Proof of Theory 1 of Boy'o Universal Theory of Therapy (BUTT) . J Med Diagn Meth S1: 005. doi: 10.4172/2168-9784.S1-005

Page 12 of 12

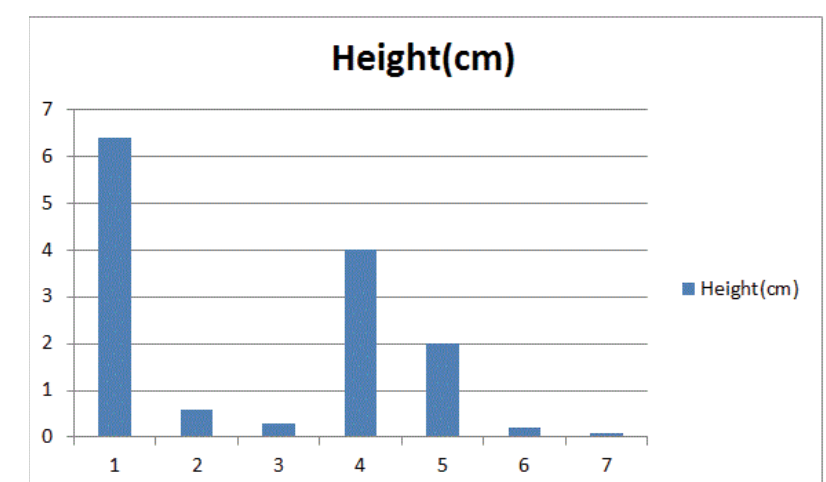

Figure 9: Graph of height of contraction of isolated rabbit ileum, $X$ axis denotes case wise list and $Y$ axis denotes height of contraction.

research is conducted from STPs line of reasoning.

\section{References}

1. Raybould HE, Glatzle J, Robin C. Expression g of $5 \mathrm{HT} 3$ receptors by extrusive duodenal afferent contribute to intestine inhibition of gastric emptying. Am J physiol gastrointestinal liver physiol 284: G367-G372.

2. Ganong FW (2002) Review of medical physiology, Mc-graw Hill Publishers page $20-30$.

3. Qingzhen J, Minggang I, Linjie W (2011) Developmental expression change of the genes involved in IGF1 signalling pathway in longissimus dorsi muscle of Tongchung and Yorkshire pigs during postnatal growth. Mol Biol Rep 38: $5133-5138$

4. Morrison DK, Davis RJ (2003) Regulation of MAP kinase modules by scaffold protein in mammals. Annu. Rev cell Dev Biol 19: 91-118.

5. Albiger B, Sandgren A, Katsuragi H, Meyer-Hoffert U, Beiter K, et al. (2005) Myeloid differentiation factor 88-dependent signalling controls bacterial growth during colonization and systemic pneumococcal disease in mice. Cell Microbio 7: $1603-1615$

6. Boy'o BI (2014) Successful regeneration of CNS nerve cell and possible bye bye to debilitating effects of neurodegenerative diseases, medical journal, date of acceptance march 13 2015, ref Ms number medical journal-14-1024R1
7. Boy'o BI (2014) Proposed Boyo Universal Theory of Therapy (BUTT), extract at www.amazon.com/dp/B00UP3Q268.

8. Ricard F, Jan T (2013) Food and symptom generating functional gastrointestinal disorder physiological aspect. AMJ Gastroenterol 108: 698-706.

9. Sternini C, Laura A, Enrigue R (2008) Endocrine cells a site of tastes in GI chemosensors. Curr Opinion Endocrinol Diabetes 15: 73-78.

10. Gainlugi C, Carmine M, Micheal VGL, Pier PC, Paul D, et al. (2002) TNFa signaling in neonatal rat cardiomyocetes definition of pathway generated from TNFa receptors. FASEB Journal 16: 1732-1737.

11. Mark L, Hwai JC (2008) A RAC/CdC-42-independent GIT/PIX/PAK signalling pathways mediates cell migration in C. elegans. Journal of PLOS Genet 4.

12. Reichrath J, Reichrath S (2002) Notch signalling in embryology and cancer

13. Guadix JA, Ruiz-Villalba A, Lettice L, Velecela V, Muñoz-Chápuli $R$, et al. (2011) Wt1 controls retinoic acid signalling in embryonic epicardium through transcriptional activation of Raldh2. Development 138: 1093-1097.

14. Brou C, Logeat F, Gupta N, Bassey C, LeBeil O, et al. (2000). A novel proteolytic cleavage involving notch signaling, the role of disintegrin metalloprotease TACE, Mol Cell 5: 207-216.

15. Halse R, Sylvie MB, Armstrong JL, McCormack JG, Yeaman SJ, et al. (2001) Control of glycogen synthesis by glucose, glycogen and insulin in cultured human muscle cells. Diabetes April 50: 720-726.

16. Peter $\mathrm{CH}$, Vincente ET (2014) Clin Invest 124: 2315-2324

17. Pohler E, Mamai O, Hirst J, Zamiri M, Horn H, et al. (2012) Haploinsufficience for alpha and gamma adaptin binding protein (AAGAB) P34 causes clinically heterogenous forms of punctuate palmoplanter keratoderma, journal of investigative dermatology 132: 589-599.

18. Brinim (2013)

19. Berkowitz G, Zhang X, Mercie R, Leng Q, Lawton M (2000) Plant Cell Physiol 41: 785-790.

20. Chen S, Hong-lian S, Xiao-WZ (2011) Molecular cloning and expression analysis of signal transduction and activation of transcription (STAT) from the Chinese white shrimp. Fenneropenaeus Chinesis Mol Biol Rep 38: 5313-5319.

21. Takashi S, Unno T, Kitazawa T, Taneike T, Yamada M, et al. (2007) Three distinct muscarinic signaling for cationic channels activation in mouse gut smooth muscle cells. J Physiol 1: 41-61.

22. Dryer J, Salmon KS, Zibrik LS, Beechey S (2005) Expression of sweet taste receptor, of the T1R family in the intestinal tract and enteroendocrine cells. Biochemical Soc Trans 33: 302-305. 